\title{
DETERMINAN KINERJA MAQASHID SYARIAH PERBANKAN SYARIAH INDONESIA
}

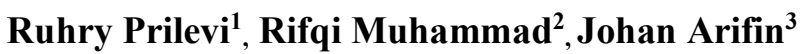 \\ 1,2,3Fakultas Ekonomi, Universitas Islam Indonesia \\ rifqimuhammad@uii.ac.id
}

\begin{abstract}
This study was conducted to evaluate the effect of return on assets (ROA), capital adequacy ratio $(C A R)$, non-performing financing (NPF) and the characteristics of sharia supervisory boards (DPS) on the performance of Maqashid Syariah in Indonesia. This study examines the performance of Maqashid Syariah based on the financial statements of 12 selected Sharia Commercial Banks (BUS) in Indonesia. The results of this study indicate that CAR has a positive influence on Maqashid Syariah, while NPF has a negative influence on Maqashid Syariah. Further investigation shows that capital adequacy is an important factor influencing Maqashid Syariah. While a high CAR value will increase public confidence in BUS. Therefore, BUS needs to apply the principle of prudence in distribution so that it can reduce the NPF so that Maqashid Syariah can be achieved in the form of welfare for stakeholders. Other results show that ROA has a positive correlation with Maqashid Syariah's performance, meaning that Islamic banks have a profit orientation but are not a top priority in their final mission. This research has implications for management to formulate its operational performance to not only pursue the commercial aspects, but also social aspects and sharia compliance to improve the performance of Maqashid Sharia which is the ideal of establishing an Islamic bank.
\end{abstract}

Keywords: Maqashid sharia, full-fledged islamic bank, Financial performance

\section{Abstrak}

Penelitian bertujuan untuk mengevaluasi pengaruh return on asset (ROA), capital adequacy ratio $(C A R)$, non performing financing (NPF) dan karakteristik dewan pengawas syariah (DPS) terhadap kinerja Maqashid Syariah di Indonesia. Penelitian ini menguji variablel penentu kinerja maqashid Syariah berdasarkan laporan keuangan 12 Bank Umum Syariah (BUS) di Indonesia terpilih. Penelitian ini menggunakan metode kuantitatif, dengan menggunakan statistik deskriptif untuk melakukan analisis penelitian. Hasil penelitian ini menunjukkan bahwa CAR memiliki pengaruh positif pada Maqashid Syariah, sedangkan NPF memiliki pengaruh negatif pada Maqashid Syariah. Investigasi lebih lanjut menunjukkan bahwa kecukupan modal merupakan faktor penting yang mempengaruhi Maqashid Syariah. Sementara nilai CAR yang tinggi akan meningkatkan kepercayaan publik pada BUS. Oleh karena itu, BUS perlu menerapkan prinsip kehati-hatian dalam penyaluran sehingga dapat mengurangi NPF agar Maqashid Syariah dapat dicapai dalam bentuk kesejahteraan bagi stakeholder. Hasil lain menunjukkan bahwa ROA memiliki korelasi positif terhadap kinerja Maqashid Syariah, artinya bahwa bank syariah memiliki orientasi terhadap laba namun bukan menjadi prioritas utama dalam misi akhirnya. Penelitian ini memiliki implikasi bagi manajemen untuk merumuskan kinerja operasionalnya untuk tidak sekedar mengejar aspek komersial samata, namun juga aspek sosial dan kepatuhan syariah untuk meningkatkan kinerja Maqashid Syariah yang menjadi cita-cita pendirian bank syariah.

Katakunci: Maqashid syariah, Bank umum Syariah, Kinerja keuangan

Cronicle of Article: Received (April 2020); Revised (May 2020); and Published (June 2020).

(C2019 Jurnal Kajian Akuntansi Lembaga Penelitian Universitas Swadaya Gunung Jati.

Profile and corresponding author: Ruhry Prilevi, Rifqi Muhammad and Johan Arifin are from Accounting Department in Faculty of Business and Economics, Universitas Islam Indonesia. Corresponding Author: rifqimuhammad@uii.ac.id

How to cite this article: Prilevi, R., Muhammad, R., \& Arifin, J., (2020). Determinan Kinerja Maqashid Syariah Perbankan Syariah Indonesia. Jurnal Kajian Akuntansi, 4 (1), 88-98. 


\section{PENDAHULUAN}

Pesatnya perkembangan perbankan syariah di Indonesia ditandai dengan jumlah Bank Umum Syariah (BUS), Unit Usaha Syariah (UUS), dan Bank Pembiayaan Rakyat Syariah (BPRS) yang semakin bertambah dari tahun ke tahun (Muhammad, 2019). Sementara, perkembangan industri keuangan syariah secara umum merupakan representasi dari mayoritas penduduk muslim yang ada di Indonesia dan didasarkan pada alasan utama yaitu adanya pandangan hukum keharaman bunga (interest) pada bank konvensional karena masuk dalam kategori riba yang dilarang dalam agama Islam. Riba diharamkan berdasarkan dalil Al Quran, As Sunnah dan kesepakatan para ulama (Ijmak), bahkan tidak ada satu syariat pun yang menghalalkan riba (Drissi \& Angade, 2019).

Dengan semakin meningkatnya jumlah Bank Umum Syariah yang ada di Indonesia maka kinerja BUS dituntut menjadi lebih baik. Pengukuran kinerja menggunakan rasio profitabilitas sering digunakan karena rasio ini dapat menggambarkan tingkat efektifitas manajemen suatu bank dalam menjalankan operasionalnya untuk mendapatkan laba (Arfiani \& Mulazid, 2017).

Namun demikian, seharusnya bank syariah seharusnya memiliki tujuan yang jauh lebih bermanfaat dibandingkan hanya untuk mencapai laba maksimum, hal ini dapat dilakukan dengan mewujudkan Maqashid Syariah (Lesmana \& Haron, 2019). Untuk dapat mencapai maqashid syariah, sebuah lembaga bisnis syariah harus mampu melakukan penjagaan pada al-aql (pikiran), addien (agama), nafs (jiwa), nasl (keturunan) dan maal (harta) (Iryani et al., 2019). Dalam konteks praktik bisnis syariah, pencapaian maqashid syariah dapat diukur melalui pencapaian tujuan berupa pendidikan individu, penciptaan keadilan dan pencapaian kepentingan publik. Pengukuran kinerja bank syariah berbasis maqashid syariah diharapkan dapat mengetahui seberapa jauh bank syariah peduli dan terlibat dalam aktivitas sosial baik dalam hubungan bank syariah dengan pegawai maupun masyarakat sekitarnya.

Menurut (Muhammad, 2020), peran dan fungsi dari lembaga perbankan yaitu memberdayakan ekonomi umat, menjadi perekat nasionalisme baru, mendorong penurunan spekulasi di pasar keuangan, memberikan return yang lebih baik, dan mendorong pemerataan pendapatan nasional. Dengan peran dan fungsi perbankan syariah di Indonesia yang begitu penting maka diperlukan adanya peningkatan kinerja agar tercipta perbankan syariah yang sehat dan efisien.

Menurut Azis (2018) kinerja perbankan syariah selama ini banyak diteliti menggunakan rasio-rasio konvensional sehingga perlu dilakukan dilakukan evaluasi terkait tujuan mereka agar sesuai dengan Maqashid syariah.

Profitabilitas merupakan rasio yang menggambarkan kemampuan sebuah perusahaan untuk mendapatkan laba dengan kemampuan dan sumber daya yang dimiliki, seperti kas, modal, kegiatan penjualan, jumlah Sumber Daya Manusia (SDM), jumlah cabang dan lain-lain, sehingga profitabilitas menjadi tolak ukur kinerja sebuah bank (Harahap, 2013).

Bank Indonesia menetapkan salah satu ukuran profitabilitas sebuah bank dengan menggunakan rasio Return on Asset (ROA). Dengan ROA sebuah perusahaan dapat mengukur efisiensi dan efektifitas untuk menghasilkan laba dengan menggunkan aktiva yang dimiliki perusahaan (Sutrisno \& Widarjono, 2018). Profitabilitas yang baik dari sebuah perusahaan menunjukkan bahwa perusahaan tersebut memiliki prospek yang baik dan mampu bertahan dalam kurun waktu yang panjang (Haryanto, 2016).

Konsep Al-Maslahah (Public Interest) yang menjadi salah satu tujuan Maqashid Syariah menggunakan elemen Profit Ratio 
dengan rumus laba perbankan dibagi dengan asset yang dimiliki oleh perbankan, sehingga semakin besar tingkat profitabilitas perbankan maka akan semakin besar pula kinerja Maqashid Syariah pada perbakan tersebut.

Capital Adequacy Ratio (CAR) mencerminkan modal yang dimiliki oleh bank untuk menghasilkan laba. Bank dengan CAR yang tinggi memberikan kesempatan bank dalam menghasilkan laba (Sutrisno \& Widarjono, 2018). Manajemen bank juga akan lebih leluasa dalam menempatkan dananya untuk aktivitas investasi yang menguntungkan untuk mendukung pengembangan operasi dan kelangsungan hidup bank. Selain itu, dengan nilai CAR yang tinggi maka bank dapat menanggung risiko yang ditimbulkan sehingga akan mampu meningkatkan profitabilitas sebuah bank. Adapun rendahnya nilai CAR disebabkan adanya peningkatan ekspansi aset berisiko dengan tidak disertai penambahan modal maka akan menurunkan kesempatan bank untuk berinvestasi dan pada akhirnya dapat menurunkan tingkat kepercayaan masyarakat kepada bank yang berpengaruh pada tingkat profitabilitas.

Apabila nilai CAR pada sebuah perbankan semakin tinggi, maka kinerja bank akan semakin sehat, hal ini akan menunjukan semakin besar kemampuan bank dalam menghadapi risiko akibat penyusunan harta. Ketika bank beroperasi dengan sehat maka akan berpengaruh terhadap tingkat kepercayaan masyarakat terhadap perbankan tersebut. Adapun kepercayaan masyarakat terhadap bank merupakan dasar konsep yang ditawarkan dalam Maqashid Syariah. Dengan kepercayaan masyarakat yang semakin tinggi terhadap perbankan tersebut maka peran bank syariah sebagai penyalur pembiayaan akan menjadi lebih baik.

Risiko yang dihadapi bank ketika menyalurkan kreditnya adalah pada saat timbulnya kegagalan bayar atau NonPerforming Financing (NPF). Bank yang memiliki nilai NPF tinggi cenderung kurang efisien. Sebaliknya bank dengan nilai NPF yang rendah cenderung dikatakan lebih efisien. Bank dengan NPF rendah mempunyai kemampuan menyalurkan dananya kepada nasabah lainnya dengan demikian bank akan memiliki tingkat profitabilitasnya yang semakin tinggi (Al Rahahleh et al., 2019). Dengan nilai NPF yang rendah tentunya bank memiliki kinerja yang lebih efisien sehingga perbankan dengan mudah mewujudkan Maqashid Syariah.

Menurut (Mujib, 2017), Dewan Pengawas Syariah (DPS) adalah lembaga pengawas syariah yang bertugas mengawasi operasional perbankan syariah agar tetap konsisten dan berpegang teguh pada prinsip Syariah. Pengawasan merupakan elemen yang penting dalam manajemen untuk menjamin tercapainya tujuan organisaasi. Dengan demikian pengawasan syariah menempati posisi yang penting dalam struktur tata keloala perbankan syariah dilihat dari segi keagamaan, sosial, ekonomi, hukum dan tata kelola (Sudi, D, 2016).

Penelitian (Muttakin \& Ullah, 2012) terhadap 30 perbankan syariah yang ada di Bangladesh menemukan bahwa semakin banyak anggota DPS maka akan mendorong kinerja yang lebih baik. Dengan banyaknya anggota DPS suatu perbankan syariah maka akan lebih memiliki kepakaran, pengalaman, keahlian dan jaringan profesional serta sosial yang lebih baik. Semakin banyak anggota DPS maka pengawasan yang dilakukan juga akan menjadi lebih baik karena tingkat kepatuhan syariah menjadi lebih baik. Dengan kepatuhan syariah yang lebih baik maka kinerja maqashid syariah menjadi lebih baik.

Disisi lain, (A. S. Rahman \& Haron, 2019) melakukan penelitian tentang dampak corporate governance pada bank-bank syariah di Indonesia dan Malaysia terhadap kinerja bank syariah berbasis Maqashid Syariah. Penelitian 
tersebut menyimpulkan bahwa karakteristik DPS dan struktur dewan direksi akan mempengaruhi kinerja bank syariah berbasis Maqashid Syariah.

Pada penelitian sebelumnya yang dilakukan oleh Azis tahun 2018 dilakukan anlisia kinerja perbankan dengan menggunakan perhitungan Maqashid Syariah. Adapun pada penelitian ini setelah dilakukan perhitungan Maqashid Syariah maka akan dilakukan pengkajian hubungannya dengan variabel-variabel kinerja keuangan dan karakteristik DPS. Pada tahun 2018, Gayatri dan Sutrisno melakukan analisa pengaruh produk dan risiko bank terhadap kinerja Maqashid Al-Shariah, dari penelitian tersebut dikembangkanlah penelitian ini dengan menggunakan variabel-variabel kinerja keuangan dan karakteristik DPS.

Dari penelitian terdahulu dapat diketahui bahwa pengukuran kinerja pada perbankan syariah lebih tepat bila menggunakan metode Maqashid Syariah, mengingat fungsi dan peran perbankan syariah tidak hanya menghasilkan profit atau keuntungan saja, namun lebih dari itu, perbankan syariah hendaknya turut mendukung dalam peningkatan pendidikan, penciptaan keadilan dan penciptaan kesejahteraan. Namun demikian saat ini kinerja perbankan syariah cenderung menggunakan rasio profitabilitas sesuai dengan standar kinerja yang ditetapkan oleh Bank Indonesia.

Penelitian ini bertujuan untuk mengkombinasikan variabel-variabel kinerja keuangan dan karakteristik DPS yang telah digunakan pada penelitianpenelitian sebelumnya untuk diuji pengaruhnya terhadap kinerja Maqashid Shariah pada perbankan syariah. Secara khusus, penelitian ini akan melakukan pengujian secara empiris pengaruh profitabilitas (ROA/Return on Asset), risiko pembiayaan (NPF/NonPerforming Financing), permodalan
(CAR/Capital Adequacy Ratio) dan karakteristik DPS (Dewan Pengawas Syariah) terhadap kinerja Maqashid Shariah pada perbankan syariah di Indonesia.

\section{LANDASAN TEORI Maqashid Syariah}

Maqashid asy-Syari'ah secara terminologis diartikan tujuan-tujuan ajaran Islam atau tujuan-tujuan pembuat syari'at (Allah) dalam menggariskan ajaran/syari'at Islam. Menurut (Azis, 2018), Syathibi disebut sebagai peletak dasar Ilmu Maqashid yang kemudian ia disebut sebagai "Bapak Maqashid asySyari'ah".

Maqashid syariah atau tujuan syariah memiliki kemaslahatan pokok yang disepakati yang mencakup 5 (lima) hal, yaitu (Jauhar, 2017): 1) Hifdz Ad-Din yaitu menjaga agama, 2) Hifdz An-Nafs yaitu menjaga jiwa, 3) Hifdz Al- 'Aql yaitu menjaga akal, 4) Hifdz Al-Mal yaitu menjaga harta. Tujuan Allah SWT untuk menetapkan tujuan dan hukum Islam tak lain adalah untuk kemaslahatan kita sebagai manusia di dunia dan di akhirat. Berdasarkan 5 (lima) konsep tujuan dasar Maqashid Syariah tersebut, maka dihasilkan konsep penilaian kinerja Maqashid Syariah. Penilaian kinerja Maqashid Syariah merupakan proses untuk menetapkan apakah bank syariah telah mencapai tujuan secara syariah (Mohammed et al., 2008). Dengan menggunakan dimensi-dimensi tersebut, penulis merumuskan indikator dimensidimensi yang akan ditetapkan berdasarkan kerangka Maqashid Syariah perbankan syariah (Mohammed et al., 2008).

Dimensi pengukuran dalam Maqashid Syariah terbagi dalam 3 kategori yaitu: pendidikan, penciptaan keadilan serta penciptaan kesejahteraan. Ukuran kinerja pertama, pendidikan diartikan bahwa perbankan syariah dituntut untuk meningkatkan pendidikan dan pelatihan bagi sumber daya manusianya 
(Mohammed et al., 2008). Dimensi yang pertama ini menggunakan rasio pengukuran berdasarkan hibah pendidikan, penelitian, pelatihan dan publisitas.

Ukuran kinerja kedua, penciptaan keadilan diartikan bahwa bank syariah dituntut untuk memastikan adanya keadilan pada setiap aktifitas yang dilakukan, melalui prinsip syariah bank bebas riba dan seluruh akad dalam perbankan syariah terbebas dari unsur ketidakadilan, yaitu maysir, gharar dan riba.

Sedangkan dimensi pengukuran kinerja Maqashid Syariah yang ketiga, penciptaan kemaslahatan diartikan bahwa perbankan syariah dituntut untuk menciptakan kesejahteraan bagi masyarakat luas dengan melalui proyek-proyek investasi dan bantuan-bantuan kepada masyarakat yang membutuhkan, seperti zakat dan infak. Rasio dalam dimensi ketiga ini meliputi rasio laba, rasio zakat dan rasio investasi di sektor riil.

\section{Syariah Enterprise Theory}

Syariah Enterprise Theory berpedoman pada kepedulian yang luas, yang menempatkan Tuhan sebagai stakeholders tertinggi dan menjadi satu-satunya tujuan hidup manusia (Azis, 2018). Seluruh kegiatan yang dilakukan oleh seorang muslim hendaknyalah didasarkan pada syariah Islam tidak terkecuali dalam aktivitas ekonomi. Dengan demikian Syariah Enterprise Theory sangat tepat apabila menjadi dasar bagi perbankan syariah untuk mewujudkan Maqashid Syariah. Maqashid Syariah dapat dipahami sebagai tujuan akhir dari syariah yang mengarah pada nilai-nilai kesejahteraan, kemanfaatan dan peniadaan penderitaan (Jauhar, 2017). Nilai-nilai etika Islam seperti nilai-nilai kejujuran, kebenaran, ketaqwaan, perasaan bahwa Allah SWT selalu mengawasi, dan independensi merupakan nilai-nilai yang perlu menjadi pondasi dalam pengembangan entitas syariah serta menjadi indikator dalam pengukuran kinerja komersial dan sosialnya (Tuan
Ibrahim et al., 2020). Oleh karena itu, perbankan syariah yang mendasarkan kegiatannya pada konsep Maqashid Syariah dalam operasionalnya dituntut untuk mengamalkan kaidah-kaidah hukum Islam, artinya perbankan syariah mendasarkan Tuhan sebagai stakeholder tertinggi, seperti yang dimaksud dalam Syariah Enterprise Theory.

\section{Teori Keagenan}

Teori keagenan menurut (Jensen \& Meckling, 1976) mendiskripsikan hubungan antara pemegang saham (shareholders) sebagai prinsipal dan manajemen sebagai agen dalam suatu kontrak kerjasama yang disebut dengan nexus of contract. Manajemen adalah pihak yang dikontrak atau diberi wewenang oleh pemegang saham (investor) untuk bekerja demi kepentingan pemegang saham.

Demikian yang terjadi pada perbankan syariah yang menerapkan maqashid syariah dalam aktifitasnya tentunya dibutuhkan sistem pengawasan yang ketat dan memadai supaya benar-benar hukumhukum Islam dapat diterapkan. Karena hal ini dapat memicu adanya conflict of interest, dimana prinsipal menghendaki adanya peningkatan kinerja sementara agen mendapatkan tekanan untuk meningkatkan kinerja. Aktifitas dalam perbankan syariah dalam hal ini di contohkan dalam peningkatan profitabilitas, peningkatan operasional, peningkatan permodalan dan peningkatan pengawasan yang dilakukan Dewan Pengawas Syariah (DPS) baik yang langsung dilakukan oleh DPS sendiri maupun memanfaatkan fungsi internal audit sebagai bagian unit pendukung pengawasan syariah (Sulub et al., 2020).

\section{Perumusan Hipotesis Penelitian}

Berdasarkan kajian penelitian sebelumnya, penelitian ini mengembangkan hipotesisi sebagai berikut:

Hubungan Return On Asset (ROA) terhadap Maqashid Syariah 
Profitabilitas atau Return On Asset (ROA) adalah rasio yang digunakan untuk menilai kemampuan perusahaan dalam mencari keuntungan. Penilaian kinerja keuangan bank menggunakan analisis ROA ini juga memberikan ukuran tingkat efektivitas manajemen suatu perusahaan (Kasmir, 2014). Sedangkan menurut Taswan (2010), ROA mengindikasikan kemampuan bank untuk menghasilkan keuntungan dengan aset yang dimiliki. Apabila ROA semakin besar maka akan menunjukan bahwa kinerja semakin baik

Melalui Surat Edaran Bank Indonesia menetapkan bahwa perolehan laba perbankan dinilai cukup tinggi apabila rasio ROA dalam rentang 0.5\%-1.25\%. Semakin tinggi ROA mengindikasikan kinerja bank semakin baik, karena return semakin tinggi. Sehingga penelitian ini menggunakan ROA sebagai tolak ukur kinerja keuangan perbankan.

Salah satu tujuan Maqashid Syariah, konsep Al-Mashlahah (Public Interest), terdapat elemen Profit Ratio yang dirumuskan menggunakan laba perbankan dibagi dengan aset yang dimiliki oleh perbankan, artinya semakin besar tingkat profitabilitas perbankan maka akan semakin besar pula kinerja Maqashid Syariah pada perbankan tersebut.

Dengan demikian berdasarkan uraian mengenai ROA maka dapat dirumuskan hipotesis sebagai berikut :

H1: Return On Asset (ROA) berpengaruh positif terhadap Maqashid Syariah.

\section{Hubungan Capital Adequacy Ratio (CAR) terhadap Maqashid Syariah}

Menurut Kuncoro dan Suhardjono (2011) CAR adalah rasio yang digunakan untuk mengetahui kemampuan bank dalam mempertahankan modal yang dimiliki. Selain itu CAR juga menunjukan kemampuan bank dalam melakukan identifikasi, pengukuran dan pengawasan terhadap risiko yang dapat berpengaruh terhadap modal bank. Semakin tinggi CAR maka semakin baik kemampuan bank untuk menanggung risiko dari setiap kredit/aktiva produktif yang berisiko. Jika nilai CAR tinggi maka bank tersebut mampu membiayai kegiatan operasional dan memberikan kontribusi yang cukup besar bagi profitabilitas. CAR yang tinggi menunjukkan bank memiliki modal yang besar sehingga semakin tinggi CAR semakin besar kredit yang disalurkan (Alhmunawwaroh dan Marliana, 2018).

Sejak akhir tahun 1995 besarnya CAR yang harus dicapai oleh suatu bank menurut Surat Edaran Bank Indonesia No.26/5/BPPP tanggal 29 Mei 1993 minimal 8\%, dan sejak akhir tahun 1997 besarnya CAR yang harus dicapai bank minimal 9\%. Besarnya CAR perbankan untuk saat ini sesuai Peraturan Bank Indonesia No.3/21/PBI 2001 minimal 8\%, sedangkan desarnya CAR sebagai Bank Umum dalam Arsitektur Perbankan Indonesia (API) minimal 12\%.

Semakin tinggi nilai CAR maka kinerja bank akan semakin sehat dan akan semakin besar kemampuan bank dalam menghadapi risiko akibat penyusutan harta. Dengan semakin sehatnya perbankan dalam beroperasi maka akan berpengaruh pada tingkat kepercayaan masyarakat terhadap perbankan tersebut. Adapun Maqashid Syariah yang di tawarkan merupakan kinerja yang mendasarkan pada kepercayaan masyarakat. Dengan adanya kepercayaan masyarakat yang tinggi terhadap perbankan tersebut maka peran bank syariah sebagai penyalur pembiayaan akan menjadi lebih baik. Dengan demikian berdasarkan uraian mengenai CAR maka dapat dirumuskan hipotesis sebagai berikut:

H2: Capital Adequacy Ratio (CAR) berpengaruh positif terhadap Maqashid Syariah

\section{Hubungan Non-Performing Financing (NPF) terhadap Maqashid Syariah}

Non-Performing Financing (NPF) adalah rasio yang menunjukan tingkat risiko 
pembiayaan bank. Menurut Muhammad (2008), Non-Performing Financing (NPF) adalah risiko pembiayaan yang diakibatkan dari tidak kembalinya pinjaman yang diberikan oleh pihak bank atau tidak kembalinya investasi yang sedang dilakukan oleh pihak bank.

Semakin tinggi tingkat Non-Performing Financing (NPF) maka akan semakin tinggi risiko kredit yang akan ditanggung oleh pihak bank. Dengan demikian apabila Non-Performing Financing (NPF) suatu bank menunjukan angka yang tinggi, maka dapat dikatakan bahwa kinerja bank tersebut kurang baik dalam proses pembiayaannya, sekaligus menunjukan bahwa tingkat risiko pemberian kredit pada bank searah tingginya dengan tingkat Non-Performing Financing (NPF) yang dihadapi oleh bank tersebut (Riyadi, 2006).

Menurut Bank Indonesia posisi NPF berada pada angka 5\%. Semakin rendah tingkat NPF mengindikasikan kredit yang disalurakan berhasil dan aman sehingga bank dapat menyalurkan kreditnya. Akibat tingginya NPF perbankan harus menyediakan pencadangan yang lebih besar sehingga pada akhirnya modal bank tidak ikut terkikis. Padahal besaran modal yang dimiliki bank akan sangat mempengaruhi besarnya ekspansi kredit. Apabila terjadi nilai NPF tinggi maka bank sebaiknya tidak menyalurkan kredit kepada nasabah.

Tujuan perbankan syariah tidak hanya dinilai dari profitabilitasnya saja, akan tetapi kesesuaiannya dan kepatuhannya pada tujuan syariah artinya apabila semakin besar tingkat NPF suatu perbankan yang disebabkan karena kegagalan dalam pengembalian kredit dan adanya kemacetan dalam aktivitas pembiayaan, maka hal ini mengindikasikan adanya ketidakpatuhan pada syariah yang berlaku maka tentu saja hal ini akan menurunkan kinerja Maqashid Syariah dalam perbankan tersebut. Dengan demikian berdasarkan uraian tersebut maka dapat dirumuskan hipotesis sebagai berikut:

H3: Non-Performing Financing (NPF) berpengaruh negatif terhadap Maqashid Syariah.

\section{Hubungan Karakteristik Dewan Pengawas Syariah (DPS) terhadap Maqashid Syariah}

Salah satu fungsi penting yang harus dimiliki oleh Bank Syariah adalah keberadaan Dewan Pengawas Syariah. Dewan pengawas syariah (DPS) diangkat oleh Rapat Umum Pemegang Saham (RUPS) atas rekomendasi Majelis Ulama Indonesia (MUI). Dewan Pengawas Syariah (DPS) bertugas memberikan nasihat dan saran kepada direksi serta mengawasi kegiatan bank agar sesuai dengan prinsip syariah (Darsono, dkk, 2017).

Penelitian Mollah dan Zaman (2015) menunjukan bahwa ukuran dewan pengawas syariah mempunyai pengaruh yang positif terhadap kinerja keuangan bank syariah. Penelitian yang lainnya Farook, dkk (2011), menunjukan semakin besar jumlah keanggotaan Dewan Pengawas Syariah, semakin besar monitoring yang dilakukan, mengindikasikan tingkat kepatuhan yang lebih besar terhadap hukum dan prinsip Islam. Dewan Pengawas Syariah akan mampu melakukan tugasnya dengan anggota yang besar jumlahnya, karena Dewan Pengawas Syariah untuk meninjau kegiatan dan memastikan kepatuhan bank pada syariat Islam (Farook, dkk, 2011).

Tugas DPS adalah melakukan monitoring kepatuhan bank syariah terhadap syariah Islam. Dengan adanya peran ini DPS dapat menekan masalah agensi. Dengan menekan masalah agensi maka peran dan tugas DPS menjadikan kinerja bank syariah menjadi lebih baik. Menurut (Sudi, D, 2016), Pengawasan merupakan elemen yang sangat penting dalam manajemen untuk mencapai tujuan organisasi. Pengawasan Syariah menempati posisi 
penting dalam struktur tata kelola perbankan syariah dilihat dari segi keagamanan, sosial, ekonomi hukum dan tata kelola. Oleh karena itu, DPS diharapkan memiliki tata kerja yang terukur untuk menghasilkan laporan pengawasan yang mempu memberikan informasi yang relevan bagi stakeholder bank syariah yang kompeten (Islam \& Bhuiyan, 2019).

Selanjutnya, DPS diharapkan memiliki pengalaman dalam pengawasan syariah di entitas syariah lainnya serta memiliki pengetahuan yang memadai dalam bidang keuangan dan perbankan syariah (Najwa et al., 2019). Jika beberapa kriteria tersebut dapat dipenuhi oleh DPS, maka laporan DPS sebagai hasil akhir fungsi pengawasan syariah akan menjadi bagian dari proses pertanggungjawaban bank syariah dalam kerangka kepatuhan syariah (Aribi et al., 2019). Dengan demikian berdasarkan uraian mengenai karakteristik DPS tersebut maka dapat dirumuskan hipotesis sebagai berikut:
H4: Karakteristik Dewan Pengawas Syariah (DPS) berpengaruh positif terhadap Maqashid Syariah.

\section{METODE PENELITIAN}

\section{Populasi dan Sampel Penelitian}

Populasi yang digunakan dalam penelitian ini adalah BUS di Indonesia yang terdaftar pada Otoritas Jasa Keuangan (OJK) selama periode 2014-2017. BUS yang menjadi objek penelitian ditentukan dengan menggunakan metode purposive sampling. Adapun Kriteria-kriteria dalam pemilihan sampel adalah sebagai berikut: 1) Perbankan syariah di Indonesia yang telah berbentuk Bank Umum Syariah (BUS) sejak tahun 2014-2017. 2) Bank Umum Syariah yang telah mempublikasikan laporan keuangan tahun 2014, 2015, 2016, dan 2017.

Berdasarkan kriteria-kriteria tersebut maka penelitian ini menggunakan data panel dari 12 BUS yang menjadi objek penelitian.

Tabel 1. Tabel Nama dan Alamat Website BUS yang Menjadi Objek Penelitian

\begin{tabular}{|l|l|l|l|}
\hline No & Nama Bank & Alamat Website & Data \\
\hline 1 & Bank Central Asia Syariah & www.bcasyariah.co.id & Laporan keuangan \\
\hline 2 & Bank Jabar Banten Syariah & www.bjbsyariah.co.id & Laporan keuangan \\
\hline 3 & Bank Muamalat Indonesia & www.muamalatbank.com & Laporan keuangan \\
\hline 4 & Bank Mega Syariah & www.bsmi.co.id & Laporan keuangan \\
\hline 5 & Bank Negara Indonesis Syariah & www.bnisyariah.co.id & Laporan keuangan \\
\hline 6 & Bank Rakyat Indonesia Syariah & www.brisyariah.co.id & Laporan keuangan \\
\hline 7 & Bank Syariah Bukopin & www.syariahbukopin.co.id & Laporan keuangan \\
\hline 8 & Bank Victoria Syariah & www.bankvictoriasyariah.co.id & Laporan keuangan \\
\hline 9 & Maybank Syariah Indonesia & www.maybanksyariah.co.id & Laporan keuangan \\
\hline 10 & Panin Bank Syariah & www.paninbanksyariah.co.id & Laporan keuangan \\
\hline 11 & BTPN Syariah & www.btpnsyariah.co.id & Laporan keuangan \\
\hline 12 & Bank Aceh Syariah & http://www.bankaceh.co.id/ & Laporan keuangan \\
\hline
\end{tabular}

\section{Metode Analisis Data}

Penelitian ini menggunakan E-Views 10 untuk melakukan analisis data. Data yang digunakan berupa data sekunder yaitu laporan keuangan BUS dari kurun waktu periode 2014-2017. Adapun dari data sekunder tersebut dilakukan pengukuran kinerja yang meliputi:

\section{Pengukuran Kinerja Berdasarkan Aspek Keuangan Return on Asset (ROA)}

Rasio ini digunakan untuk mengukur kemampuan bank dalam memperoleh keuntungan secara keseluruhan yang dirumuskan dengan:

$$
\text { ROA }=\frac{\text { Laba Sebelum Pajak }}{\text { Total Aktiva }} \times 100 \%
$$

\section{Non-Performing Finance (NPF)}

NPF digunakan untuk mengetahui tingkat resiko pembiayaan yang bermasalah atas piutang baik pembiayaan lancar maupun 
kurang lancar. Adapun rumus untuk menghitung NPF yaitu:

$\mathrm{NPF}=\underline{\text { Pembiayaan Bermasalah }} \times 100$

$$
\text { Total Pembiayaan }
$$

\section{Capital Adequacy Ratio (CAR)}

CAR adalah kemampuan yang dimiliki oleh bank dalam menutup risiko kerugian yang ditimbulkan dari aktivitas yang dilakukannya dan kemampuan yang dimiliki oleh bank dalam mendanai kegiatan operasionalnya. Nilai CAR dapat diperoleh menggunakan rumus:

$\mathrm{CAR}=\underline{\text { Modal Sendiri }} \times 100 \%$

$$
\text { ATMR }
$$

\section{Pengukuran Kinerja Berdasarkan Aspek Non Keuangan}

Good Corporate Governance merupakan sistem pengelolaan yang merancang peningkatan kinerja suatu bank, melindungi kepentingan stakeholder dan meningkatkan kepatuhan terhadap perundang-undangan serta nilai etika yang berlaku secara umum (Faozan, 2013). Berkaitan dengan masalah agensi yaitu bank tidak menjalankan operasional usahanya sesuai syariah Islam, maka dibutuhkan mekanisme Good Coorporate Governance dengan pembentukan DPS.

Fakor-faktor yang berpengaruh terhadap kinerja DPS dalam penelitian (A. A. Rahman \& Bukair, 2013) adalah sebagai berikut: jumlah anggota DPS, lintas keanggotaan DPS, kualifikasi pendidikan DPS, DPS dengan reputasi yang baik, keahlian DPS, skor penilaian DPS. Number of Board Members, Cross Membership, Secular Educational Qualifications, Reputable SSB Members, Expertise of Shariah Supervisory Board, Shariah Supervisory Board Score. Adapun dalam penelitian ini karakteristik Dewan Pengawas Syariah meliputi: 1) Jumlah Dewan Pengawas Syariah, 2) Perangkapan Jabatan Dewan Pengawas Syariah pada unit perbankan yang lain. 3) Kualifikasi Pendidikan Dewan Pengawas Syariah. 4) Reputasi keanggotaan organisasi nasional

\section{Pengukuran Kinerja Berdasarkan} Aspek Maqashid Syariah

Formulasi untuk melakukan evaluasi kinerja pada perbankan syariah berdasarkan konsep Maqashid Syariah telah dilakukan oleh (Zahrah, 2014). Variabel-variabel yang digunakan meliputi Tahdzib al-Fard (Pendidikan), Iqamah alAdl (menegakan keadilan) dan Maslahah (kesejahteraan). Ketiga variabel tersebut diuraikan menjadi 9 dimensi yang kemudian dikategorikan dalam 10 elemen. Yang selanjutnya selanjutnya 10 elemen tersebut disebut rasio kinerja menurut (Mohammed et al., 2008). Ketiga tujuan Maqashid Syariah dikembangkan oleh (Mohammed et al., 2008) dapat dijelaskan sebagai berikut:

\begin{tabular}{|c|c|c|c|c|}
\hline $\begin{array}{l}\text { Tujuan/Konsep } \\
\text { Syariah }\end{array}$ & Dimensi (D) & Elemen (E) & Rasio Kinerja (R) & Sumber Data \\
\hline \multirow{4}{*}{$\begin{array}{l}\text { Education } \\
\text { (Tahdzib Al- } \\
\quad \text { Fard) }\end{array}$} & \multirow{2}{*}{$\begin{array}{l}\text { D1. Advancement of } \\
\text { Konwledge }\end{array}$} & $\begin{array}{l}\text { E1. Education } \\
\text { Grant }\end{array}$ & \multirow{2}{*}{$\begin{array}{l}\text { R1. Education Grant or } \\
\text { Scholarship /Total Expense } \\
\text { R2. Research Expense / Total } \\
\text { Expense }\end{array}$} & Annual Report \\
\hline & & E2. Research & & Annual Report \\
\hline & $\begin{array}{l}\text { D2. Instilling New Skill } \\
\text { and Improvements }\end{array}$ & E3. Training & $\begin{array}{l}\text { R3. Training Expense/ Total } \\
\text { Expense }\end{array}$ & Annual Report \\
\hline & $\begin{array}{l}\text { D3. Creating } \\
\text { Awareness of Islamic } \\
\text { Banking }\end{array}$ & E4. Publicity & $\begin{array}{l}\text { R4. Publicity Expense/ Total } \\
\text { Expense }\end{array}$ & Annual Report \\
\hline \multirow{3}{*}{$\begin{array}{l}\text { Justice } \\
\text { (Al-'Adl) }\end{array}$} & D4. Fair Returns & $\begin{array}{l}\text { E5. } \\
\text { Returns }\end{array}$ & \multirow{2}{*}{$\begin{array}{l}\text { R5. Profit Equalization } \\
\text { Reserves (PER) /Net or } \\
\text { Investment Income } \\
\text { R6. Mudharabah and } \\
\text { Susyarakah Modes/Total } \\
\text { Investment Modes }\end{array}$} & Annual Report \\
\hline & $\begin{array}{l}\text { D5. Cheap Product } \\
\text { andand Services }\end{array}$ & $\begin{array}{l}\text { E6. Functional } \\
\text { Distribution }\end{array}$ & & Annual Report \\
\hline & $\begin{array}{l}\text { D6. Elimination of } \\
\text { Negative Element that } \\
\text { Breed Injustices }\end{array}$ & $\begin{array}{l}\text { E7. Interest } \\
\text { Free Product }\end{array}$ & $\begin{array}{l}\text { R7. Interest Free } \\
\text { Income/Total Income }\end{array}$ & Annual Report \\
\hline
\end{tabular}

\section{Tabel 2. Model Pengukuran Kinerja Maqashid Syariah}


Ruhry Prilevi, Rifqi Muhammad, Johan Arifin

Determinan Kinerja Maqashid Syariah Perbankan Syariah Indonesia

\begin{tabular}{|c|c|c|c|c|}
\hline \multirow{3}{*}{$\begin{array}{l}\text { Public Interest } \\
\text { (Al-Mashlahah) }\end{array}$} & $\begin{array}{l}\text { D7. Profitability of } \\
\text { Bank }\end{array}$ & $\begin{array}{ll}\text { E8. } & \text { Profit } \\
\text { Ratios } & \end{array}$ & R8. Net Income/Total Aset & Annual Report \\
\hline & $\begin{array}{l}\text { D8. Redistribution of } \\
\text { Income and Welth }\end{array}$ & $\begin{array}{l}\text { E9. Personal } \\
\text { Income }\end{array}$ & R9. Zakah Paid/Net Aset & Annual Report \\
\hline & $\begin{array}{l}\text { D9. Investment } \\
\text { Vital Real Sector }\end{array}$ & $\begin{array}{l}\text { E10. Investment } \\
\text { Ratio in Real } \\
\text { Sector }\end{array}$ & $\begin{array}{l}\text { R10. Investmen in Real } \\
\text { Economis Sector/Total } \\
\text { Investment }\end{array}$ & Annual Report \\
\hline
\end{tabular}

1) Tahdzib Al-Fard, maqashid pertama yang memiliki arti perlunya dikembangkan pengetahuan dan keahlian bagi tiap individu sehingga terjadi peningkatan nilai spiritualnya. 2) Iqamah Al-Adl, maqashid kedua yang memiliki arti bahwa bank syariah harus jujur dan wajar dalam bertransaksi dan melakukan aktivitas bisnis yang meliputi produk, harga, dan perjanjian kontrak. 3) Maslaha, maqashid ketiga yang memiliki arti bahwa bank syariah harus mampu melakukan pengembangan proyek investasi dan jasa sosial dalam meningkatkan kesejahteraan masyarakat.

Setelah diklasifikasikan dalam 10 rasio selanjutnya dilakukan pembobotan melalui proses verifikasi dengan melakukan wawancara dengan para pakar syariah di Asia dan Timur Tengah (Antonio et al., 2012). Pembobotan dari setiap konsep ditunjukan pada Tabel adalah sebagai berikut:

\section{Tabel 3. Bobot Konsep dan Elemen Pengukuran Indeks Maqashid Syariah}

\begin{tabular}{lclc}
\hline Tujuan Syariah (Konsep) & $\begin{array}{c}\text { Bobot } \\
\text { Rata-rata (\%) }\end{array}$ & Elemen (E) & $\begin{array}{c}\text { Bobot Rata- } \\
\text { rata (\%) }\end{array}$ \\
\hline Education (Tahdzib Al-Fard) & $30^{*}$ & E1. Education Grant & $24^{*}$ \\
& & E2. Research & $27^{*}$ \\
& & E3. Training & $26^{*}$ \\
& & E4. Publicity & $\mathbf{1 0 0}$ \\
Justice (Al- Adl) & & Total & $30^{*}$ \\
& $41^{*}$ & E5. Fair Returns & $32^{*}$ \\
Public interest (Al-Mashlahah) & & E6. Functional Distribution & $38^{*}$ \\
& & E7.Interest Free Product & $\mathbf{1 0 0}$ \\
& $29 *$ & Total & $33^{*}$ \\
& & E8. Profit Ratios & $30^{*}$ \\
& & E9. Personal Income & $37^{*}$ \\
\hline
\end{tabular}

Sumber: Data Diolah, 2019

Keterangan *:

Merupakan angka pembobotan dari konsep dan elemen Maqashid Syariah yang diperoleh dari hasil wawancara dengan para pakar syariah di Asia dan Timur Tengah (Mohammed, dkk. 2008 dalam Antonio, dkk. 2012)

Analisis data yang dilakukan pada penelitian menggunakan software E-View 10 terdiri dari model Analisis Statistik Deskriptif, Analisis Uji Asumsi Klasik dan Analisis Model Regresi Data Panel.

\section{Tabel 4. Hasil Analisis Statistik Deskriptif}

\begin{tabular}{lccccc}
\hline & Maqashid & ROA & CAR & NPF & DPS \\
\hline Mean & 0.275559 & 0.002342 & 0.225800 & 0.060015 & 2.234375 \\
Median & 0.261226 & 0.007750 & 0.193650 & 0.038600 & 2.000000 \\
Maximum & 0.834469 & 0.112000 & 0.758300 & 0.439900 & 3.750000 \\
Minimum & -0.015357 & -0.201300 & 0.115100 & 0.000000 & 1.250000 \\
Sta Deviasi & 0.115586 & 0.047875 & 0.122198 & 0.082890 & 0.640824 \\
Observasi & 48 & 48 & 48 & 48 & 48 \\
\hline
\end{tabular}

Dalam penelitian ini Statistik Deskriptif digunakan adalah rata-rata (mean), nilai tengah (median), minimum, maksimum dan standar deviasi

Sumber: Data Diolah, 2019 
Hasil pengujian Analisis Diskriptif pada variabel terikat Maqashid Syariah didapatkan data nilai minimum -0.015357 , nilai maximum 0.834469 dan nilai mean sebesar 0.275559 .

Uji asumsi klasik yang digunakan meliputi uji Normalitas dan Heteroskedastisitas.

Hasil analisis uji normalitas menggunakan E-views 10, terlihat dalam Tabel 4.3. nilai probabilitas Jarque-Bera kurang dari 5\% ( $>0,05)$, yaitu sebesar 0,02. Dengan demikian data dianggap berkualitas atau distribusi data normal.
Pada tabel hasil uji Heteroskodeksitas menggunakan Uji-White dalam software eviews 10 menunjukkan bahwa nilai Prob. Chi-squere $=0,5054$ atau lebih besar daripada $0,05(>0,05)$ dengan kata lain tidak terjadi gejala heteroskedastisitas.

Sedangkan analisa Estimasi parameter model regresi menggunakan data panel, menggunakan tiga jenis model pendekatan yaitu Common Effect, Fixed Effect, Random Effect. Berikut hasil pengujian ketiga model regeresi tersebut:

\section{Tabel 5. Hasil Regresi Common Effect Model (CEM)}

\begin{tabular}{lllll}
\hline Variable & Coefficient & Std. Error & t-Statistic & Prob. \\
\hline Konstanta & 0.174252 & 0.65699 & 2.652258 & 0.0114 \\
ROA & 0.025182 & 0.495827 & 0.050788 & 0.9597 \\
CAR & 0.479772 & 0.118526 & 4.047806 & 0.0002 \\
NPF & -0.824064 & 0.289079 & -2.850652 & 0.0069 \\
DPS & 0.018963 & 0.021890 & 0.866301 & 0.3915 \\
R-squared & & 0.531648 & & \\
Adjusted R-squared & & 0.449686 & & \\
Prob(F-statistic) & & 0.000000 & & \\
\hline
\end{tabular}

Sumber: Data Diolah, 2019

Tabel 6. Hasil Regresi Fixed Effect Model (FEM)

\begin{tabular}{lllll}
\hline Variable & Coefficient & Std. Error & t-Statistic & Prob. \\
\hline C & 0.397804 & 0.208373 & 1.909100 & 0.0653 \\
ROA & -0.012641 & 0.531462 & -0.023786 & 0.9812 \\
CAR & 1.079350 & 0.259828 & 4.154094 & 0.0002 \\
NPF & -0.845977 & 0.271970 & -3.110554 & 0.0039 \\
DPS & -0.141052 & 0.096894 & -1.455730 & 0.1552 \\
R-squared & & 0.806256 & & \\
Adjusted R-squared & & 0.715439 & & \\
Prob(F-statistic) & & 0.000000 & & \\
\hline
\end{tabular}

Sumber: Data Diolah, 2019

Tabel 7 Hasil Uji Normalitas

\begin{tabular}{llll}
\hline F-statistic & 0.799473 & Prob. F(4,43) & 0.5322 \\
\hline Obs*R-squared & 3.322638 & Prob. Chi-Square(4) & 0.5054 \\
Scaled explained SS & 3.983790 & Prob. Chi-Square(4) & 0.4082 \\
\hline
\end{tabular}

Sumber: Data Diolah, 2019 


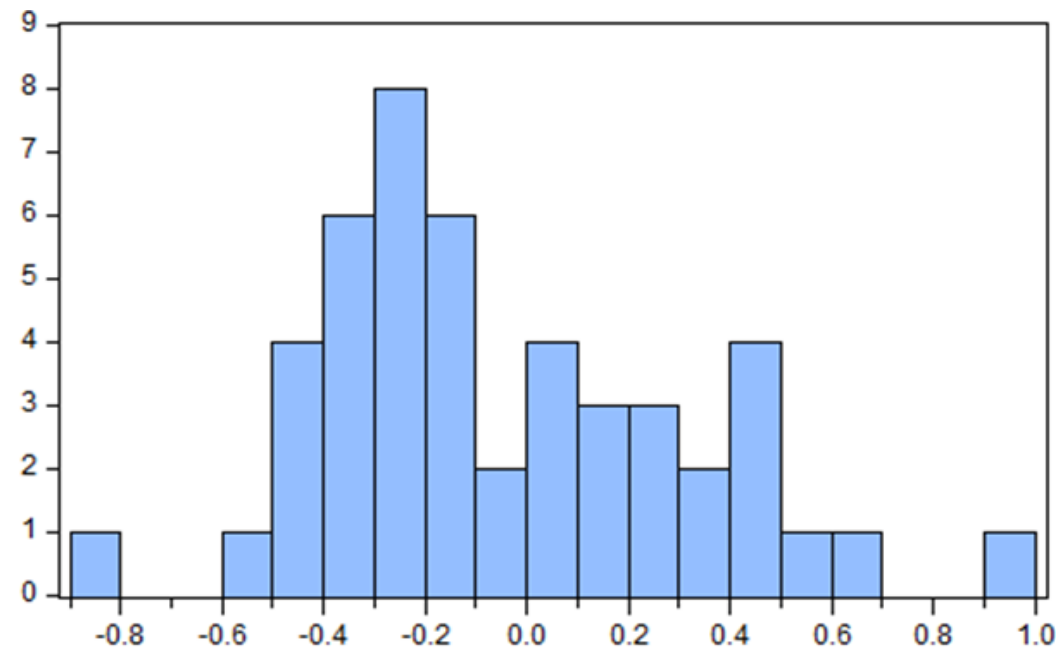

\begin{tabular}{ll}
\hline \multicolumn{2}{l}{ Series: Residuals } \\
Sample 148 \\
Observations 47 \\
Mean & -0.049359 \\
Median & -0.144493 \\
Maximum & 0.946617 \\
Minimum & -0.836002 \\
Std. Dev. & 0.359296 \\
Skewness & 0.513742 \\
Kurtosis & 2.986294 \\
& \\
Jarque-Bera & 2.067825 \\
Probability & 0.355613
\end{tabular}

\section{Gambar 1. Hasil Uji Normalitas}

Dalam pemilihan model regresi yang paling sesuai dengan data yang digunakan dalam penelitian ini diuji dengan menggunakan:

F-Stat atau Uji Chow (Common Effects vs Fixed Effects)

Pengujian F-Stat menggunakan hipotesis sebagai berikut:

H0 : Common Effect Model (CEM)

$\mathrm{Ha} \quad$ : Fixed Effect model (FEM)

Dengan asumsi sebagai berikut:

H0: apabila p-value $>0,05$, maka Common Effect Model (CEM) diterima.

Ha: apabila $p$-value $<0,05$, maka Fixed Effect model (FEM) diterima.

Dari hasil pengujian didapatkan nilai pvalue adalah 0.000005 . Nilai p-value sebesar 0.000005, lebih kecil dari nilai disyaratkan sebesar 0.05. Dengan demikian maka $\mathrm{Ha}$ diterima, artinya Tabel 9. Hasil Uji Hausman

\begin{tabular}{llll}
\hline Test Summary & Chi-Sq. Statistic & Chi-Sq. d.f. & Prob. \\
\hline Cross-section random & 11.594847 & 4 & 0.0206 \\
\hline
\end{tabular}

Sumber: Data Diolah, 2019

Tabel 10 Hasil Uji Model F-Stat

\begin{tabular}{lllll}
\hline Variable & Coefficient & Std. Error & t-Statistic & Prob. \\
\hline C & 0.157848 & 0.065188 & 2.421426 & 0.0198 \\
ROA & 0.089677 & 0.492359 & 0.182137 & 0.8563 \\
CAR & 0.509711 & 0.117698 & 4.330673 & 0.0001 \\
NPF & -0.812105 & 0.284795 & -2.851542 & 0.0067 \\
DPS & 0.022890 & 0.021847 & 1.047759 & 0.3006 \\
R-squared & & 0.492124 & & \\
Adjusted R-squared & & 0.444879 & & \\
Prob(F-statistic) & & 0.000005 & & \\
\hline
\end{tabular}

estimasi persamaan regresi lebih tepat bila menggunakan Fixed Effect Model (FEM).

Uji Hausman Test (Fixed Effect vs Random Effects)

Pengujian Hausman hipotesisnya adalah sebagai berikut:

H0: Random Effect Model (REM)

Ha: Fixed Effect model (FEM)

Dengan asumsi sebagai berikut:

H0: apabila p-value $>0,05$ maka Random Effect Model (REM) diterima

Ha: apabila jika, p-value $<0,05$ maka Fixed Effect model (FEM) diterima

Pada pengujian Hausman didapatkan nilai p-value adalah 0.0206. Nilai p-value sebesar 0.0206, lebih kecil dari nilai disyaratkan sebesar 0.05. Dengan demikian maka Ha diterima, artinya estimasi persamaan regresi lebih tepat bila menggunakan Fixed Effect Model (FEM)

Sumber: Data Diolah, 2019 
Uji Lagrange Multiplier (Common Effects vs Randam Effects).

Pengujian Langrange Multiplier hipotesisnya adalah sebagai berikut:

H0 : Common Effect Model (CEM)

$\mathrm{Ha}:$ Random Effect model (REM)

Dengan asumsi sebagai berikut:

H0: apabila p-value $>0,05$ maka Common

Effect Model (CEM) diterima

Ha: apabila p-value $<0,05$ maka Random

Effect model (REM)

Tabel 11. Hasil Uji Model Lagrange Multiplier

\begin{tabular}{llll}
\hline Test & Statistic & d.f. & Prob. \\
\hline Breusch-Pagan LM & 98.11690 & 66 & 0.0063 \\
Pesaran scaled LM & 2.795418 & - & 0.0052 \\
\hline
\end{tabular}

Sumber: Data Diolah, 2019

Setelah dilakukan tiga metode pengujian yang berdasarkan uji F-Stat, uji Hausman dan uji Lagrange Multiplier maka Fixed Effect Model (FEM) terpilih sebagai metode yang paling sesuai dalam penelitian ini. Pada Tabel 4 ditunjukan perbandingan dari 3 model analisis Common Effect Model (CEM), Fixed Effect Model (FEM) dan Random Effect Model (REM

Dari Tabel 4 dapat diketahui bahwa diperoleh hasil bahwa Fixed Effect Model (FEM) mempunyai koefisien determinasi yang paling besar bila dibandingkan dengan dua metode yang lain, Common Effect Model (CEM) dan Random Effect Model (REM). Berdasar hasil uji kelayakan model dan nilai koefisien determinasi, maka Fixed Effect Model (FEM), adalah model yang paling tepat digunakan untuk memprediksi pengaruh variabel ROA, CAR, NPF, DPS terhadap variabel Maqashid Syariah.

Berdasarkan pemilihan model akhir dapat diketahui bahwa model terbaik untuk regresi data panel berdasarkan dari uji asumsi klasik maka dapat ditentukan model terbaik adalah Fixed Effect Model.
Dari hasul uji Langrange Multiplier maka akan didapatkan nilai p-value adalah 0.0052 . Nilai p-value sebesar 0.0052, lebih kecil dari nilai disyaratkan sebesar 0.05 . Dengan demikian maka Ha diterima, artinya estimasi persamaan regresi lebih tepat bila menggunakan Random Effect Model

(REM).
Tabel 5 menunjukan hasil analisis model dari Fixed Effect, sebagai berikut:

Dari Tabel 5 korelasi sebesar 0.806256 (RSquared) menunjukkan bahwa variabel independen memiliki pengaruh sebesar $80,6 \%$ sisanya sebesar $19,4 \%$ dipengaruhi oleh variabel lain $(100 \%-80,6 \%)$. Nilai adjusted $\mathrm{R}^{2}$ semakin mendekati1, maka model ini cukup baik. F-statistik pada output regresi menunjukkan validitas atas model yang diestimasi, karena nilai $p$ value dari f-stat bernilai 0.000000 (Prob (F-statistic)) yang mengindikasikan signifikansi dengan tingkat keyakinan 95\% $(\alpha=5 \%)$. Pengaruh variabel ROA, CAR, NPF dan DPS secara parsial, dengan menggunakan pengujian eViews 10 ditunjukan pada Tabel 6 sebagai berikut: Berdasarkan Tabel 6 maka dapat disajikan dalam bentuk persamaan di bawah ini:

MAQASHID $=0.157848+0.089677$ $(\mathrm{ROA})+0.509711(\mathrm{CAR})-0,812105$ $(\mathrm{NPF})+0.022890$ (DPS).

Dibawah ini merupakan Tabel yang merangkum hubungan yang terjadi pada variabel bebas terhadap variabel terikatnya yang ditunjukkan oleh Tabel sebelumnya

Tabel 12. Hasil Perbandingan Metode Common Effect, Fixed Effect dan Random Effect

\begin{tabular}{llll}
\hline Model & Common Effect & Fixed Effect & Random \\
\hline R-Squared & 0.531648 & 0.806256 & 0.642398 \\
Adjusted R-Squared & 0.449686 & 0.715439 & 0.609132 \\
Prob (F-Statistic) & 0,000000 & 0,000000 & 0,000000 \\
\hline
\end{tabular}


Ruhry Prilevi, Rifqi Muhammad, Johan Arifin

Determinan Kinerja Maqashid Syariah Perbankan Syariah Indonesia

Tabel 13. Hasil Uji Fixed Effect Model

\begin{tabular}{lllll}
\hline Model & Fixed Effect & Persen & Keterangan & \\
\hline R-Squared & 0.806256 & $80,6 \%$ & $\begin{array}{l}\text { Menunjukkan mempunyai } \\
\text { sebesar 80,6 persen }\end{array}$ & \\
Adjusted R-Squared & 0.715439 & $71,5 \%$ & Nilainya mendekati 1 & \\
Prob (F-Statistic) & 0,000000 & $95 \%$ & & \\
\hline
\end{tabular}

Sumber: Data Diolah, 2019

Tabel 14. Hasil Uji Koefisien Determinasi

\begin{tabular}{lllll}
\hline Variable & Coefficient & Std. Error & t-Statistic & Prob. \\
\hline C & 0.157848 & 0.065188 & 2.421426 & 0.0198 \\
ROA & 0.089677 & 0.492359 & 0.182137 & 0.8563 \\
CAR & 0.509711 & 0.117698 & 4.330673 & 0.0001 \\
NPF & -0.812105 & 0.284795 & -2.851542 & 0.0067 \\
DPS & 0.022890 & 0.021847 & 1.047759 & 0.3006 \\
\hline
\end{tabular}

Sumber: Data Diolah, 2019

Tabel 15. Hubungan Variabel Bebas (ROA, CAR, NPF, dan DPS) Terhadap Variabel Terikat (Maqashid Syariah)

\begin{tabular}{|c|c|c|c|c|c|}
\hline Variabel & Koefisien & $\begin{array}{l}\text { Hubungan } \\
\text { ditemukan }\end{array}$ & yang & Probabilitas & $\begin{array}{l}\text { Hasil Pengujian } \\
\text { Hipotesis }\end{array}$ \\
\hline Coefficient & 0.157848 & Positif $(+)$ & & 0.0198 & - \\
\hline ROA & 0.089677 & Positif $(+)$ & & 0.8563 & Tidak Didukung \\
\hline CAR & 0.509711 & Positif (+) & & 0.0001 & Didukung \\
\hline NPF & -0.812105 & Negatif (-) & & 0.0067 & Didukung \\
\hline DPS & 0.022890 & Positif $(+)$ & & 0.3006 & Tidak Didukung \\
\hline
\end{tabular}

Sumber: Data Diolah, 2019

\section{PEMBAHASAN}

Pengaruh Variabel ROA terhadap Variabel Maqashid Syariah

ROA dalam perbankan syariah adalah rasio yang digunakan untuk menghitung kemampuan bank syariah dalam memperoleh laba (profitabilitas). ROA dirumuskan membandingkan laba bersih dengan aset yang dimiliki oleh perusahaan (Sutrisno, 2017). Hal ini menggambarkan kemampuan manajemen bank untuk menghasilkan keuntungan dengan memanfaatkan aset yang tersedia dari bank.

Dari hasil perhitungan koefisien regresi variabel ROA menunjukkan bahwa nilai koefisien ROA sebesar 0,089677 atau yang berarti bahwa setiap kenaikan ROA sebesar $1 \%$ akan menaikkan Maqashid Syariah sebesar 8,96 \%, dengan asumsi variabel lainnya konstan. Sedangkan hasil probability sebesar $0.8563>0,05(5 \%)$ yang berarti ROA berpengaruh tidak signifikan terhadap Maqashid Syariah. Dengan demikian dapat disimpulkan bahwa ROA berpengaruh positif terhadap Maqashid Syariah pada tingkat kepercayaan 95\% tidak berpengaruh signifikan selama periode tahun 20142017 pada perbankan syariah di Indonesia. Hal ini tidak sejalan dengan hipotesis yang dirumuskan dalam penelitian ini, bahwa ROA berpengaruh positif terhadap Maqashid Syariah.

Ketidaksesuaian hubungan antara ROA dengan Maqashid Syariahkemungkinan dapat terjadi sesuai dengan pandangan (Jumansyah \& Syafei, 2013), bahwa perbankan syariah tidak hanya dituntut untuk meraih profit saja, namun lebih dari itu ada tujuan-tujuan yang sesuai syariah Islam yang harus dicapai oleh BUS. Tujuan tersebut adalah peningkatan pendidikan, terciptanya keadilan dan terciptanya kemaslahatan. Dengan demikian ROA tidak berpengaruh pada Maqashid Syariah, karena adanya tuntutan BUS untuk meraih tujuan sesuai hukum atau syariat Islam. 
Kemungkinan lain yang dapat menjelaskan bahwa ROA tidak berpengaruh terhadap Maqashid Syariah, karena terdapat profitabilitas yang digunakan untuk menutupi kegagalan pembiayaan, sehingga hubungan ROA dengan Maqashid Syariah menjadi berlawanan arah. Hal lain yang dapat juga terjadi karena laba yang diperoleh bank tersebut digunakan untuk menutup beban-beban operasional yang digunakan untuk kegiatan operasionalnya yang dilakukan oleh Bank Umum Syariah.

Pengaruh Variabel CAR terhadap Variabel Maqashid Syariah

CAR dalam perbankan syariah merupakan rasio yang digunakan untuk yang menunjukkan kemampuan suatu bank dalam menyediakan dana untuk mengatasi kemungkinan risiko kerugian yang dialami, CAR disebut juga sebagai rasio kecukupan modal. Rasio ini penting karena dengan menjaga CAR pada batas minimal $8 \%$ nasabah akan terlindungi secara keseluruhan dan sistem keuangan akan terjaga (Sutrisno, 2017). Semakin meningkat nilai CAR menggambarkan bahwa perbankan memiliki kemampun dalam menghadap risiko kerugian semakin meningkat.

Dari hasil perhitungan koefisien regresi variabel CAR menunjukkan bahwa nilai koefisien CAR sebesar 0.509711 artinya bahwa setiap kenaikan CAR sebesar 1\% akan menaikkan nilai Maqashid Syariah sebesar 50,9 \%, dengan asumsi variabel lainnya konstan. Sedangkan hasil probability sebesar $0.0001<0,05 \quad(5 \%)$ artinya CAR berpengaruh signifikan terhadap Maqashid Syariah. Dengan demikian dapat disimpulkan bahwa CAR berpengaruh positif terhadap Maqashid Syariah, dan pada tingkat kepercayaan 95\% berpengaruh signifikan selama periode tahun 2014-2017 pada perbankan syariah di Indonesia.

Hal ini sejalan dengan hipotesis yang dirumuskan dalam penelitian ini, bahwa CAR berpengaruh positif terhadap Maqashid Syariah. CAR berpengaruh positif terhadap profitabilitas dan akhirnya meningkatkan nilai Maqashid Syariah. Tingginya rasio modal dapat melindungi nasabah dan meningkatkan kepercayaan masyarakat terhadap perbankan, dan pada akhirnya meningkatkan pendapatan suatu bank. Dan pada saat meningkatkan pendapatan suatu bank maka meningkatkan pula nilai Maqashid Syariah dari bank tersebut.

Pengaruh Variabel NPF terhadap Variabel Maqashid Syariah

NPF dalam perbankan syariah merupakan rasio yang menunjukan besarnya kredit bermasalah yang dihadapi sebuah perbankan syariah (Sutrisno \& Widarjono, 2018). Dari hasil perhitungan koefisien regresi variabel NPF menunjukkan bahwa nilai koefisien NPF sebesar -0.812105 artinya setiap kenaikkan NPF sebesar 1\% akan menurunkan Maqashid Syariah sebesar 81,2 \%, dengan asumsi variabel lainnya konstan. Sedangkan hasil probability sebesar $0.0067<0,05 \quad(5 \%)$ yang berarti NPF berpengaruh signifikan terhadap Maqashid Syariah. Dengan demikian dapat disimpulkan bahwa NPF berpengaruh negatif terhadap Maqashid Syariah dan pada tingkat kepercayaan 95\% berpengaruh signifikan selama periode tahun 2014-2017 pada Perbankan Syariah di Indonesia.

Hal ini sejalan dengan hipotesis yang dirumuskan, bahwa NPF berpengaruh negatif terhadap Maqashid Syariah. Dalam dunia perbankan, pembiayaan merupakan produk yang menghasilkan pendapatan terbesar, namun demikian pembiayaan juga dapat menjadi sumber bencana bagi sebuah perbankan syariah. Pembiayaan dapat dikatakan sebagai pendapatan yang menguntungkan apabila dalam penyalurannya menggunakan prinsip kehati-hatian, sehingga pembiayaan akan menjadi pembiayaan yang tepat sasaran. Namun demikian pembiayaan menjadi sumber bencana apabila dalam menyalurkan pembiayaan perbankan tidak menggunakan prinsip kehati-hatian, 
sehingga menyebabkan pembiayaan menjadi bermasalah bahkan menjadi macet. Dengan macetnya pembiayaan ini maka akan mengurangi pendapatan perbankan tersebut sehingga mengurangi pula nilai Maqashid Syariah dari perbankan Syariah.

Pengaruh Variabel DPS terhadap Variabel Maqashid Syariah

Dari hasil perhitungan koefisien regresi variabel DPS menunjukkan bahwa nilai koefisien DPS sebesar 0.022890 artinya bahwa setiap peningkatan koefisien DPS sebesar $1 \%$ akan menaikkan Maqashid Syariah sebesar 2,2 \%, dengan asumsi variabel lainnya konstan. Sedangkan hasil probability sebesar $0.3006>0,05(5 \%)$ yang berarti DPS berpengaruh tidak signifikan terhadap Maqashid Syariah. Dengan demikian dapat disimpulkan bahwa DPS berpengaruh positif terhadap Maqashid Syariah, dan pada tingkat kepercayaan 95\% berpengaruh tidak signifikan selama periode tahun 20142017 pada Perbankan Syariah di Indonesia.

Hal ini tidak sejalan dengan hipotesis yang dirumuskan, bahwa karakteristik DPS berpengaruh positif terhadap Maqashid Syariah. Hasil analisis pada penelitian ini sejalan dengan penelitian yang dilakukan oleh (Sudi, D, 2016), yang menyebutkan bahwa sistem pengawasan yang ada pada perbankan syariah tidak memadai untuk membuat DPS melakukan pengawasan yang efektif. Sehingga karakteristik DPS berpengaruh tidak signifikan terhadap kinerja Maqashid Syariah.

Berikut kemungkinan yang dapat dilakukan agar DPS dapat melakukan pengawasan dengan efektif, yaitu:

1) Jumlah DPS

Penempatan keanggotaan DPS pada BUS atas persetujuan dari Dewan Pengawas Nasional (DSN), dimana keanggotaannya diatur bahwa setiap lembaga keuangan syariah harus memiliki sedikitnya tiga orang anggota Dewan Pengawas Syariah
(DPS), dimana salah satu dari jumlah tersebut ditetapkan sebagai ketua.

Dari data DPS yang diperoleh dari 12 BUS yang menjadi sampel penelitian selama tahun 2014-2017 dapat diamati bahwa tidak banyak BUS yang memiliki jumlah DPS sebanyak 3 (tiga) orang. Pada tahun 2014 dan 2015: Bank Jabar Banten Syariah, Bank Muamalat dan Bank Mega Syariah, adapun pada tahun 2016 dan 2017: Bank Jabar Banten Syariah dan Bank Muamalat. Sedangkan diluar bank tersebut rata-rata jumlah Dewan Pengawas Syariah sebanyak 2 (dua) orang. Oleh karena itu hal ini dimungkinkan menjadi kendala keterbatasan pengawasan kinerja DPS.

2) Perangkapan jabatan DPS pada unit perbankan lain

Mengacu pada peraturan yang ada bahwa anggota DPS boleh merangkap sebagai anggota DPS pada lembaga lain dengan jumlah 4 (empat) Lembaga Keuangan syariah (LKS) sehingga total jabatan sebanyak 5 Lembaga Keuangan syariah (LKS ).

Dari data DPS yang diperoleh dari 12 BUS yang menjadi sampel penelitian selama tahun 2014-2017 dapat diamati bahwa dari tahun 2014 sampai 2017 seluruh anggota DPS memiliki perangkapan jabatan baik pada BUS ataupun UUS yang lainnya. Walaupun perangkapan jabatan yang dilakukan masih dalam batas sesuai dengan peraturan yang ada. Namun demikian dengan adanya perangkapan jabatan tersebut dimungkinkan menjadi kendala bagi seorang anggota DPS dalam melaksanakan tugas dan kewajibannya.

3) Kualifikasi Pendidikan DPS

Peraturan BI sebagai penjabaran UU menetapkan kualifikasi anggota DPS dengan kriteria bahwa anggota DPS harus memenuhi sejumlah kriteria terkait dengan integritas, kompetensi dan reputasi keuangan. Adapun kompetensi diukur dengan kriteria memiliki pengetahuan dan pengalaman di bidang syariah muamalah dan pengetahuan di bidang perbankan dana 
atau keuangan secara umum, yang ditunjukan dengan ijasah pendidikan formal, surat keterangan atau sertifikat dari lembaga pendidikan dan pelatihan dana atau DSN-MUI. Dari data DPS yang diperoleh dari 12 BUS yang menjadi sampel penelitian selama tahun 2014-2017 dapat diamati bahwa hampir seluruh anggota DPS memiliki kualifikasi pendidkan tinggi, yaitu bergelar master dan doktor. Hanya saja kalau dilihat dari bidang keilmuan, komposisi antara mereka yang berlatar belakang ekonomi dan mereka yang berlatar belakang studi Islam sangat tidak berimbang. Dari mereka yang berlatar belakang studi Islam tidak semuanya bergelut di bidang keuangan syariah, melainkan hanya bergelut bidang keilmuan Islam. Oleh karena itu hal ini dimungkinkan menjadi kendala keterbatasan pengawasan kinerja DPS. Temuan ini sejalan dengan rekomendasi (Noordin \& Kassim, 2019) bahwa komposisi DPS dengan pengetahuan dan pengalaman yang memadai baik dengan proses training dan Pendidikan formal berkelanjutan akan memberikan kontribusi dalam menyiapkan DPS dalam menyusun laporan pengawasan syariah yang mampu meningkatkan kepercayaan investor dan stakeholder lain.

4) Reputasi keanggotaan pada organisasi nasional

Dari data DPS yang diperoleh dari 12 BUS yang menjadi sampel penelitian selama tahun 2014-2017 dapat diamati bahwa terdapat 2 kemungkinan yang terjadi apabila anggota DPS memiliki reputasi keanggotaan pada organisasi nasional, yaitu: 1) DPS memiliki tingkat kepercayaan yang tinggi mampu melaksanakan tugas sebagai DPS dengan baik, 2) Kinerja DPS menjadi bias apabila DPS mempunyai perangkapan jabatan baik pada organisasi nasional ataupun pada BUS. Misal: dalam menetukan anggota DPS yang harus sepersetujuan anggota BPN.

\section{SIMPULAN DAN SARAN Simpulan}

Berdasarkan hasil analisis yang telah dilakukan, maka dapat diperoleh kesimpulan sebagai berikut:

\section{Pengaruh ROA terhadap Maqashid Syariah.}

Hasil penelitian menunjukan bahwa ROA berpengaruh tidak signifikan terhadap Maqashid Syariah. Hal ini bertentangan dengan hipotesis penelitian. Dengan demikian hasil dari penelitian ini adalah kinerja Maqashid Syariah tidak dipengaruhi oleh ROA. Hasil penelitian sesuai dengan pendapat (Jumansyah \& Syafei, 2013), yang menyatakan bahwa tujuan perbankan syariah tidak hanya diukur dari keuntungan yang diperoleh, akan tetapi lebih dari itu utk mewujudkan tujuan-tujuan syariah, seperti yang dimaksud dalam teori Maqashid Syariah.

\section{Pengaruh CAR terhadap Maqashid Syariah.}

Hasil penelitian menunjukan bahwa permodalan dalam hal ini CAR berpengaruh signifikan terhadap Maqashid Syariah. Hal ini sejalan dengan hipotesis penelitian. Dengan demikian tingginya nilai CAR menunjukan kecukupan modal yang dimiliki oleh BUS tersebut, maka nasabah secara keseluruhan akan terlindungi sehingga sistem keuangan akan terjaga, yang pada akhirnya menumbuhkan tingkat kepercayaan masyarakat terhadap BUS tersebut, sehingga akan meningkatkan kinerja Maqashid Syariah.

\section{Pengaruh NPF terhadap Maqashid Syariah.}

Hasil penelitian ini menunjukan bahwa nilai NPF berpengaruh negatif secara signifikan terhadap Maqashid Syariah. Hal ini sejalan dengan hipotesis penelitian ini bahwa NPF berpengaruh negarif terhadap kinerja Maqashid Syariah. Pembiayaan bagi BUS merupakan sumber penghasilan, apabila terjadi kemacetan, maka meningkatkan nilai NPF, ketika terjadi kredit macet dan kegagalan dalam proses 
pembiayaan maka BUS tersebut akan kesulitan mencapai Maqashid Syariah.

Pengaruh Dewan Pengawas Syariah terhadap Maqashid Syariah

Hasil penelitian ini menunjukan bahwa karakteristik DPS berpengaruh tidak signifikan terhadap Maqashid. Hal ini bertentangan dengan hipotesis bahwa karakteristik DPS berpengaruh positif terhadap Maqashid Syariah. Adapun hasil dari penelitian yang mengatakan bahwa karakteristik DPS tidak berpengaruh pada kinerja Maqashid Syariah hal ini dapat terjadi karena adanya beberapa pemicu, kurangnya efektifnya sistem pengawasan yang dilakukan oleh DPS dalam penerapan hukum-hukum syariah pada BUS, disebabkan kurangnya jumlah anggota DPS dari ketentuan setidaknya 3 orang, di beberapa BUS hanya terdapat 2 DPS, dengan kecukupan jumlah Dewan Pengawas Syariah (DPS) maka akan tercukupi pengawasan pada kepatuhan syariah baik pada level manajemen maupun penentuan bagi hasil. Adanya perangkapan jabatan DPS pada BUS atau lembaga syariah yang lainnya, Adanya kualifikasi pendidikan dan perlunya pelatihan bagi DPS yang kurang memadai. Hal inilah yang dapat dijadikan pemicu karakteristik DPS tidak berpengaruh terhdap kinerja Maqashid Syariah.

\section{Saran}

Berdasarkan kesimpulan diatas, penulis mencoba merumuskan saran antara lain:

\section{Bagi Bank Umum Syariah.}

Berdasarkan hasil analisis hubungan dengan Maqashid Syariah antara nilai profitibilitas dan karakteristik DPS berpengaruh tidak signifikan, sedangkan hubungan antara nilai permodalan dan operasional berpengaruh signifikan, untuk itu BUS dituntut untuk lebih meningkatkan aspek sosial melalui Maqasid Syariah. Selain itu Bank Syariah dapat memberikan kewenangan yang lebih luas lagi terhadap Dewan Pengawas Syariah, sehingga pelaksanaan Maqasid
Syariah dapat lebih maksimal. Selain itu juga perlunya pihak BUS untuk lebih memperhatikan faktor-faktor yang dapat meningkatkan kinerja bank berdasarkan kinerja Maqashid Syariah, tidak hanya faktor-faktor yang bersifat profit saja. Peningkatan aspek sosial yang dapat dilakukan oleh BUS seperti misalnya peningkatan pendidikan, pelatihan, training dan publikasi baik kepada sumber daya perbankan maupun masyarakat terhdap ilmu-ilmu perbankan syariah, sedangkan pemberian kewenangan pada DPS dengan tujuan supaya BUS di dalam operasionalnya patuh pada syariat Islam.

\section{Bagi Pemerintah.}

Dalam hal ini pemerintah berperan sebagai penentu regulasi, kedepan diperlukan alat ukur kinerja untuk BUS yang berbeda dari Bank Umum Konvensional, dan kinerja Maqashid Syariah diharapkan dapat menjadi tolak ukur dimana kinerja BUS tidak hanya dituntut dari pengukuran profitabilitas saja akan tetapi juga Maqashid Syariah, yang meliputi: pertama peningkatan pendidikan baik bagi karyawan maupun masyarakat luas, kedua terciptanya keadilan dalam kegiatan BUS hendaknya meniadakan transaksi yang mengandung riba, mayshir dan gharar, ketiga terciptanya kemaslahatan atau kebermanfaatan bagi masyarakat luas sehingga tercipta kemakmuran bukan hanya golongan tetapi seluruh aktifitas yang terlibat dengan BUS.

\section{Bagi Kalangan Akademisi.}

Penelitian terkait kinerja Maqashid Syariah dan faktor-faktor yang mempengaruhinya masih sangat terbatas. Sehingga penelitian terkait kinerja Maqashid Syariah pada BUS di Indonesia masih sangat perlu untuk dikembangkan. Adapun untuk penelitian selanjutnya indikator penelitian dapat diganti atau ditambah atau dibandingkan dengan negara lainnya, dengan menggunakan pilihan variabel yang berpengaruh pada Maqashid Syariah baik pada BUS, UUS, ataupun lembaga keuangan lainnya. 


\section{DAFTAR PUSTAKA}

Al Rahahleh, N., Ishaq Bhatti, M., \& Najuna Misman, F. (2019).

Developments in Risk Management in Islamic Finance: A Review. Journal of Risk and Financial Management, 12(1), 37. https://doi.org/10.3390/jrfm12010037

Antonio, M. S., Sanrego, Y. D., \& Taufiq, M. (2012). An Analysis of Islamic Banking Performance: Maqashid Index Implementation in Indonesia and Jordania. Journal of Islamic Finance, 1(1), 12-29.

Arfiani, L. R., \& Mulazid, A. S. (2017). Analisis Faktor-Faktor yang Mempengaruhi Tingkat Bagi Hasil Simpanan Mudharabah pada Bank Umum Syariah Indonesia Studi Kasus pada Bank Umum Syariah di Indonesia Periode 2011-2015. IQTISHADIA: Jurnal Ekonomi \& Perbankan Syariah, 4(1), 1-23. https://doi.org/10.19105/iqtishadia.v4 i1.1132

Aribi, Z. A., Arun, T., \& Gao, S. (2019). Accountability in Islamic financial institution: The role of the Shari'ah supervisory board reports. Journal of Islamic Accounting and Business Research, 10(1), 98-114. https://doi.org/10.1108/JIABR-102015-0049

Azis, M. T. (2018). Analisis Kinerja Perbankan Syariah Indonesia Ditinjau dari Maqashid Syariah. Al-Amwal, 10(1), 1-17.

Drissi, S., \& Angade, K. (2019). Islamic Financial Intermediation the Emergence of a New Model. European Journal of Islamic Finance, 12(April), 1-7. https://doi.org/10.13135/2421$2172 / 2880$
Faozan, A. (2013). Implementasi Good Corporate Governance dan Peran Dewan Pengawas Syariah di Bank Syariah. Jurnal Ekonomi Islam, 7(1), 1-14.

Harahap, S. S. (2013). Analisis Kritis atas Laporan Keuangan. Raja Grafika Grafindo Persada.

Haryanto, S. (2016). Profitability Identification of National Banking Through Credit, Capital Structure, Efficiency and Risk Level. Jurnal Dinamika Manajemen, 7(1), 11-21.

Iryani, L. D., Yadiati, W., Supardi, E. M., \& Triyuwono, I. (2019). The Moderating Effect of Shariah Governance on Financial and Maqasid Shariah Performance: Evidence from Islamic Banks in Indonesia. The Journal of Social Sciences Research, 5(52), 264-274. https://doi.org/10.32861/jssr.52.264.2 74

Islam, K. A., \& Bhuiyan, A. B. (2019). The Theoretical Linkages between the Shariah Supervisory Board ( SSB ) and Stakeholder Theory in the Islamic Financial Institutes : An Empirical Review. International Journal of Accounting \& Finance Review, 4(2), 43-49.

Jauhar, A. A.-M. H. (2017). Maqashid Syariah. Amzah Bumi Aksara.

Jensen, M. C., \& Meckling, W. H. (1976). Theory of the firm: Managerial behaviour, agency cost and ownership sturcture. Journal of Financial Economics, 3(4), 305-360.

Jumansyah, \& Syafei, A. W. (2013). Analisis Penerapan Governance Business Syariah dan Pencapaian Maqashid Syariah Bank Syariah di Indonesia. Jurnal Al Azhar Indonesia: Seri Pranata Sosial, 2(1), 25-38. 
Lesmana, S., \& Haron, M. H. (2019). Maqasid Shariah Based Performance of Islamic Banks, Islamic Corporate Governance, and Contingency Theory : a Theoretical. International Journal of Accounting, Finance and Business (IJAFB), 4(24), 70-86.

Mohammed, M. O., Abdul-Razak, D., \& Fauziah Md Taib. (2008). The Performance Measures of Islamic Banking Based on the Maqasid Framework. IIUM International Accounting Conference (INTAC IV), $1-17$.

Muhammad. (2020). Manajemen Keuangan Syariah: Analisis Fiqh dan Keuangan. UPP STIM YKPN.

Muhammad, R. (2019). Akuntansi Keuangan Syariah: Konsep dan Implementasi PSAK Syariah. P3EI Press.

Mujib, A. (2017). Dewan pengawas Syariah (DPS) pada Lembaga Keuangan Mikro Syariah di Wilayah Jawa tengah. Az Zarqa, 9(1), 125145.

Muttakin, M. B., \& Ullah, M. S. (2012). Corporate governance and bank performance: Evidence from Bangladesh. Corporate Board: Role, Duties and Composition, 8(1), 62-68.

Najwa, N. A., Ramly, Z., \& Haron, R. (2019). Board Size, Chief Risk Officer and Risk-taking in Islamic Banks: Role of Shariah Supervisory Board. Jurnal Pengurusan, 57. https://doi.org/10.17576/pengurusan2019-57-01

Noordin, N. H., \& Kassim, S. (2019). Does Shariah committee composition influence Shariah governance disclosure?: Evidence from Malaysian Islamic banks. Journal of Islamic Accounting and Business
Research, 10(2), 158-184. https://doi.org/10.1108/JIABR-042016-0047

Rahman, A. A., \& Bukair, A. A. (2013). The Influence of the Shariah Supervision Board on Corporate Social Responsibility Disclosure by Islamic Banks of Gulf Co-Operation Council Countries. Asian Journal of Business and Accounting, 6(2), 65104.

Rahman, A. S., \& Haron, R. (2019). The Effect of Corporate Governance on Islamic Banking Performance: A Maqasid Shari'ah Index Approach on Indonesian Islamic Banks. 8(Special Issue), 001-018.

Sudi, D, M. (2016). Efektifitas Dewan Pengawas Syariah pada Perbankan Syariah. DeePublish.

Sulub, S. A., Salleh, Z., \& Hashim, H. A. (2020). Corporate governance, SSB strength and the use of internal audit function by Islamic banks: Evidence from Sudan. Journal of Islamic Accounting and Business Research, 11(1), 152-167. https://doi.org/10.1108/JIABR-122016-0148

Sutrisno. (2017). Pengukuran Kesehatan Bank Syariah dengan Sharia Compliance and Performance. Jurnal Keuangan Dan Perbankan, 21(1), 133-143.

Sutrisno, \& Widarjono, A. (2018).

Maqasid sharia index, banking risk and performance cases in Indonesian islamic banks. Asian Economic and Financial Review, 8(9), 1175-1184. https://doi.org/10.18488/journal.aefr. 2018.89.1175.1184

Tuan Ibrahim, T. A. F., Hashim, H. A., \& Mohamad Ariff, A. (2020). Ethical values and bank performance: 
Jurnal Kajian Akuntansi, Vol. 4 No. 1 2020, 78-98 e2579-9991, p2579-9975

http://jurnal.unswagati.ac.id/index.php/jka

evidence from financial institutions in Malaysia. Journal of Islamic

Accounting and Business Research, 11(1), 233-256.
https://doi.org/10.1108/JIABR-112016-0139

Zahrah, M. A. (2014). Ushul Figh. Pustaka Firdaus. 